\title{
Apoptosis, ROS and Calcium Signaling in Human Spermatozoa: Relationship to Infertility
}

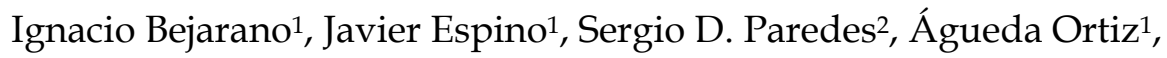 \\ Graciela Lozano ${ }^{1}$, José Antonio Pariente ${ }^{1}$, Ana B. Rodríguez ${ }^{1}$ \\ ${ }^{1}$ University of Extremadura, Department of Physiology \\ ${ }^{2}$ Complutense University of Madrid, \\ Department of Physiology (School of Medicine) \\ Spain
}

\section{Introduction}

Apoptosis or programmed cell death is a physiological process involving a finely regulated cascade of biochemical events. The main features of this pathway are the activation of specific proteases such as caspases, the release of pro-apoptotic mitochondrial factors, and finally changes in nuclear morphology and DNA fragmentation. Throughout the apoptotic process, one of the responsible signals for initiating the process of programmed cell death is a sustained and manteined increase in intracellular calcium levels $\left(\left[\mathrm{Ca}^{2+}\right]_{\mathrm{i}}\right)$. Experimental evidence suggests that an increase in $\left[\mathrm{Ca}^{2+}\right]_{\mathrm{i}}$ could be associated with the apoptotic signal. In fact, an overload of $\left[\mathrm{Ca}^{2+}\right]_{i}$ due to depletion of intracellular stores or calcium influx from the extracellular medium has been suggested to be a signal that precedes the apoptotic process. Additionally, apoptosis also can be stimulated by oxidizing agents such as hydrogen peroxide and menadione, and inhibited by antioxidants.

Mainly two pathways have been described inducing apoptotic cell death, which differ in how the death signal is transduced. The first is the extrinsic pathway, triggered by binding of extracellular death ligands, such as factor activating ExoS ligand (FasL), to its cell-surface death receptor, such as Fas. Membrane death receptors form a complex known as the deathinducing signaling complex, which recruits procaspase- 8 becoming activated caspase- 8 , and subsequently processes other downstream caspases. The second is the intrinsic pathway, which is mediated by mitochondrial alterations. The protein Bid, a natural substrate of caspase- 8 , is the nexus between the extrinsic and intrinsic pathway. In response to apoptotic stimuli, several proteins are released from the mitochondrial intermembrane space into the cytoplasm. Such mitochondrial alterations stimulate the generation of reactive oxygen species (ROS), which together with activation of DNAses by caspases and mitochondrial signals, undergo DNA damage.

The apoptotic process has been described in many cell types, including both sperm and intratesticular germ cells from different animal species, including humans. The process is similar to that carried out in somatic cells. Apoptosis may play a major role at causing diseases related to male infertility. Actually, it is known that apoptosis is involved in the genesis of several diseases of the male genital tract as defective spermatogenesis, decreased 
sperm motility, sperm DNA fragmentation, testicular torsion, varicocele and immunological infertility.

On the other hand, melatonin is known to regulate seasonal and circadian rhythms of mammals, but emerging evidence suggests that melatonin possesses protective effects against free radicals and apoptosis. For this reason, this indolamine appears to be a good candidate to improve sperm quality and protect from oxidative stress. Little is known, however, about the mechanisms that carry out such effects. In this regard, melatonin, which has an uncommonly low toxicity profile, may be used as a powerful free-radical scavenger, and anti-apoptotic agent in ejaculated human spermatozoa to supplement sperm preparation media, therefore increasing success of assisted reproductive techniques. Moreover, characterization of the role of melatonin on apoptosis and oxidative damage in ejaculated human spermatozoa may be helpful to preserve high rates of functional spermatozoa after manipulation for their use in any assisted reproduction program.

\section{Apoptosis}

Apoptosis is a basic biological principle of programmed cell death that occurs in almost every cell type (Kerr et al., 1972). It is a physiological process initiated by environmental or developmental stimuli, which are in charge of removing redundant cells, and maintains tissue homeostasis in a safe and non-immunogenic manner, whereas necrosis leads to plasma membrane rupture, release of pro-inflammatory intracellular molecules and collateral tissue damage (Kerr et al., 1972). The activation of a genetic program that controls designs and initiates a cascade of events leads the cell forward an organized and noiseless destruction. Apoptosis does not take place randomly, but it is a process with energy requirements, like ATP. Additionally it does not initiate inflammatory response, allowing the elimination of undesirable cells without modifying the architecture and physiology of tissues around. A major component of the apoptotic machinery involves a family of aspartic acid-directed cysteine proteases, called caspases (cysteinyl aspartate-specific proteases), which cleave multiple protein substrates en masse, leading to the loss of cellular structure and function and, ultimately, resulting in cell death (Stennicke \& Salvesen, 1997). Traditionally, two general apoptotic pathways have been described. The first is the extrinsic pathway, triggered by binding of an extracellular death ligand, such as factor activating ExoS ligand (FasL), to its cell-surface death receptor, such as Fas (Ashkenazi \& Dixit, 1998). The second is the intrinsic pathway, which is mediated by mitochondrial alterations. In response to apoptotic stimuli, several proteins are released from the mitochondrial intermembrane space into the cytoplasm (Green \& Reed, 1998). Some of the wellcharacterized proteins include cytochrome $c$, which mediates the activation of caspase-9 (Li et al., 1997), thus triggering a cascade of caspase activation, including caspase-3, that promotes cellular self-destruction.

Reproductive phenomena are also under these regulation events. These include from the development of germ cells (spermatogenesis and oogenesis), follicular development and maturation, to the interaction of gametes with subsequent fertilization and embryo implantation. For instance, in human beings, after twenty weeks of development, females show 7 millions of germ cells, which are decreased to 2 millions of ovocytes in birth and finally 300,000 in the beginning of sexual maturity (Baker, 1963). Further than $90 \%$ of ovocytes in ovary degenerate throughout the reproductive period of life (Hsueh et al., 1994). Theoretically, a normal testicle losses $75 \%$ of spermatozoa due to the degeneration of germ 
cells throughout the spermatogenesis (Rodríguez et al., 1997). In human reproductive system, cell death can be observed in ovocyte degeneration (Morita \& Tilly, 1999), in follicular atresia (Hsueh y cols., 1994), in ovulation (Murdoch, 2000), in the luteolisis (Davis \& Rueda, 2002) and in germ cells of testis (Sinha-Hikim \& Swerdloff, 1999; Koji, 2001). In males who suffer infertility from unknown origin, increased DNA damage and subsequent fragmentation of oligonucleosome in sperm cells have been reported. The presence of apoptotic signals in spermatozoa has been controversial for long time, especially due to the low transcriptional activity in these cells (Grunewald et al., 2005) and the inability to transfer studies on somatic cells to sperm behavior. Early works denied the existence of apoptosis in human ejaculated spermatozoa (Weil et al., 1998) and others have considered that the presence of endogenous debris in ejaculated spermatozoa indicates incomplete maturation during spermatogenesis (Sakkas et al., 1999a). Nonetheless, the presence and activation of apoptotic signals in human spermatozoa in response to various stimuli, is presently widely accepted (Eley et al., 2005; Barroso et al. 2006; Bejarano et al., 2008; Lozano et al., 2009).

During spermatogenesis, germ cells are in continuous proliferation, being apoptosis the process in charge of maintaining the homeostasis in testis. The hormonal control, both central (exerted by adenohypophysis FSH) and local (exerted by testosterone in Leydig cells), acts as the main mechanism for spermatogenesis regulation, as well as regulating pathway-specific apoptotic genes and proteins rather than proliferation (Ruwanpura et al., 2010). Damages in DNA (intrinsic pathway) and the signal when a ligand binds to specific death membrane receptors (extrinsic pathway) are the major mechanisms to trigger apoptosis in germ cells (Ruwanpura et al., 2010).

The ejaculated sperm deposited in the female reproductive tract must be subjected to a rigorous controlled program of senescence, so that they can activate mechanisms for removal from the cervix and uterine cavity (Aitken \& Koppers, 2011). Phosphatidylserine externalization is a typical signal of apoptosis in somatic cells. It is thought that externalized phosphatidylserine in the surface of sperm is a consequence of apoptosis triggered by oxidative stress suffered in the female tract (Lozano et al., 2009). This phenomemon seem to activate the phagocytic cells responsible for senescent spermatozoa elimination (Kurosaka et al., 2003). Thus, leukocyte antigens recognize and phagocytize sperm without an inflammatory reaction. However, phosphatidylserine exposure is not only related to apoptosis in sperm but also is associated with a decreased ability to fertilize (Said et al., 2005). In 2003, De Vries and colleagues published a paper linking the externalization of phosphatidylserine in the training process (De Vries et al., 2003); and in 2005, it was reported the externalization of this phospholipid after induction of acrosome reaction by calcium ionophore A23187 (Martin et al., 2005). Other authors found a reduced capacitation and subsequent acrosome reaction in sperm that had externalized phosphatidylserine (Grunewald et al., 2006).

Signs of apoptosis in mature spermatozoa are found primarily associated with the mitochondrial pathway: activation of initiator caspase-9, disruption of mitochondrial membrane potential, activation of the main executioner caspase- 3 and subsequent cellular collapse (Paasch et al., 2004; Bejarano et al., 2008). Experimental evidence points to an apparent exclusive cellular location of active caspase-3 to the mid-piece of spermatozoa (Oehninger et al., 2003). This is consistent with the fact that mitochondria are mainly located in that area, and also consistent with mitochondrial association of caspases- 3 decribed by Nicholson (Nicholson, 1999). 
Moreover, caspases are a family of cysteinyl aspartic-specific proteases which represent the central component of apoptotic machinery. Caspases are involved in both physiological processes, like spermatogenesis, and andrological pathologies, including varicocele, immunological infertility and reduced sperm fertilizing potential (Said et al., 2004). Besides other apoptotic events, caspase activity has been associated with spermatozoa immaturity, low count, reduced motility (Marchetti et al., 2004), decreased fertilization rates (Grunewald et al., 2008) and loss of plasma membrane integrity, as shown by phosphatidylserine externalization (Paasch et al., 2004).

Another point of connection between apoptosis and sperm capacitation is associated with the cytosolic protease calpain and its natural inhibitor calpastatin. Both proteins are located between the plasma membrane of sperm and the acrosome (Yudin et al., 2000). Calpain is a calcium-dependent protease, involved in sperm capacitation, acrosome reaction and cell fusion, which are essential processes for ovum fertilization. Numerous studies have shown the relationship between calpain and sperm motility and acrosome reaction (Ozaki et al., 2001). Caspase-1, a pro-inflammatory and executioner cystein-protease of apoptosis, is activated in human sperm within the activation cascade of caspases in response to apoptosis stimuli (Paasch et al., 2004). Caspase-1 cleaves directly calpastatin resulting in an increased activity of calpain (Wang et al., 1998). These results together, suggest that apoptotic signals are activated by capacitation and acrosome reaction, and consequently calpain performs an enhancing effect on apoptosis. Other studies showed that inhibition of both caspase- 1 and calpain partially suppresses the capacitation process without apoptosis signaling, supporting the relevant role of both proteases for capacitation and fertilization capacity in human sperm. In this line, inhibition of $\left[\mathrm{Ca}^{2+}\right]_{i}$ sensor, calmodulin, inhibited events related to capacitation, as well as triggering a strong activation of caspases -9 and -3 , with a previous disruption of mitochondrial membrane potential. Thus, these findings suggest that apoptosis and capacitation are inverse processes in human sperm. Although apoptotic spermatozoa are not able to be capacitated, capacitated spermatozoa present inhibition apoptosis signaling (Grunewald et al., 2009b). Therefore a strong dependence of $\left[\mathrm{Ca}^{2+}\right]_{\mathrm{i}}$ is displayed by both processes apoptosis and capacitation. This is consistent with results showing caspase-3 dependence of calcium signaling (Bejarano et al., 2008).

On the other hand, several studies have shown evidence on the effects of some factors on caspases and their relationship to male infertility. For example, treatment with prolactin, besides causing spermatogonial apoptosis, augments significantly caspase activity in testicular tissue when treated simultaneously with cycloheximide, a well-known pesticide (Yazawa et al., 2000). However, the pancaspase inhibitor z-VAD-fmk inhibits prolactininduced apoptosis in germ cells, which indicates the essential role of caspases in prolactininduced apoptosis (Yazawa et al., 2001). But in general, exposure to antiandrogens increases both expression and activity of caspases in a dose-dependent manner, as revealed by experiments carried out with flutamine (Omezzine et al., 2003).

Caspase- 8 constitutes a key factor in crosstalk between the two propagation pathways of death signals, especially when activated by external cytokines. Upon activation by external death signals, caspase- 8 can directly either activate executioner caspases or truncate the Bcl-2 family member, Bid, into $\mathrm{tBid}$, which, once truncated, translocates from cytosol to mitochondria where it promotes permeability and release of cytochrome $c$ (Lee et al., 1999). 


\subsection{Extrinsic apoptosis}

The extrinsic pathway constitutes another main manner to trigger apoptosis by external signals through specific death receptors, called FAS receptors. This pathway has been shown being activated in physiologically and experimentally-induced apoptosis in germinal cells (Shaha, 2007). Fas expression in human testis is related to cellular degeneration within the meiosis process, arresting maturation during the spermatogenesis. Evidence indicates that Fas gene expression is likely involved in the elimination of defective germ cells which have alterations in meiotic maturation (Francavilla et al., 2002). A massive apoptotic wave appears in early stages of normal mature spermatozoa in order to keep the ratio between some germinal cell stages and Sertoli cells. In addition, it has been shown that Sertoli cells express FasL, which lead to the destruction of Fas-positive germ cells, thereby limiting the germ cell population to a number that Sertoli cells can support (Celik-Ozenci et al., 2006). Such events are in agreement with the "abortive apoptosis", theory which proposes that apoptotic processes start in germinal cells but are not completed, and therefore Fas-positive sperm can be found in ejaculated semen. In this regard, in normal sperm, less than $10 \%$ of spermatozoa are Fas-positive. However, in oligozoospermic samples and in men whose spermatozoa have poor motility and morphology Fas-positive spermatozoa oscillates between 10-50\% (Sakkas et al., 1999a). Although, some authors have reported no evidence of Fas expression in ejaculated sperm, neither non-normozoospermic nor normozoospermic patients (Perticarari et al., 2008), a recent study has confirmed the presence of a low Fas expression, asserting its ability as selected apoptotic marker on cell surface of ejaculated spermatozoa (Soleimani et al., 2010). The triggered apoptosis in germinal cells could be attributed to a molecular mechanism which avoids the transmission of any abnormality to offspring (Koji, 2001).

Northern blottings carried out in mouse testis have shown that this organ represent the main constitutive source of FasL in the organism (Suda et al., 1993). Fas system is involved in the control of immune system and is responsible of autoimmune diseases when it is not functional. Bellgrau and collegues reported that allografts of testes were accepted in mice, unless they were derived from gld mice (non-functional FasL), or were grafted into lpr mice (lack of Fas). They also showed that Sertoli cells were identified as the testicular cells that express FasL and this receptor was therefore proposed to be responsible for immune privilege in the testis (Bellgrau et al., 1995). However, other researchers sustain that the expression or overexpression of FasL induce proinflammatory immune response after alloand xeno-transplantation (Allison et al., 1997). Additionally, Riccioli and collegues showed that through Fas system cells express FasL on germ cells surface, and not on Sertoli cells as showed by other authors, therefore discarding the theories of maintenance of immunoprivilege and regulation of physiological germ cells apoptosis. Given that FasL is present in germ cell membrane, FasL may represent a self-defence mechanism against lymphocytes present in the female genital tract, as corroborated experimentally (Riccioli et al., 2003). Experimental evidence carried out on mice revealed the presence of FasL on epididymal spermatozoa, suggesting that this system plays a self-protective role of male gametes against immune attacks along the male and female genital tract (Riccioli et al., 2003). Supplementary studies have shed new light about the role of Fas depending on its location. Two different forms of Fas were observed in sperm: Membrane cell bound (mFas) and soluble Fas (sFas) besides of matrilisyn (MMP-7), the methalloprotease which cleaves $\mathrm{mFas}$ to sFAS. mFas was found on normozoospermic men and it was absent in sperm cells 
from pathological donors suggesting that normozoospermic germ cells are equipped with Fas system protection against hostility into human genital tract. On the other hand, germ cells from infertile samples showed matrilysin and sFas, and consequently they are prone to suffer apoptotic process in human genital tract (Riccioli et al., 2005).

Apart from the physiological role of Fas, many external toxicants have been described to cause cell damage where Fas takes an essential part triggering apoptosis. For instance, bisphenol A, a potential endocrine disruptor and testicular toxicant, induces germ cell apoptosis through Fas/FasL and the subsequent activation of the mitochondrial apoptotic pathway (Wang et al., 2010). Zearalenone, which is a non-steroidal estrogenic mycotoxin, causes testicular toxicity through the modulation of Fas/FasL (Jee et al., 2010). Lead-induced apoptosis is involved in the increase of Fas expression (Dong et al., 2009). Intra-peritoneal injection of ethanol in mice also causes a rise in Fas/FasL expression. Moreover, this toxicant causes damage to mitochondria, activating the intrinsic pathway of apoptosis (Jana et al., 2010). In this line many toxicants have been shown to promote apoptosis through Fas pathway, including cocaine (Jia et al., 2008), dexamethasone (Khorsandi et al., 2008), mono(2-ethylhexyl) phthalate (Chandrasekaran et al., 2005), among others. Additionally, the gonads are very sensitive to exogenous stimuli such as X-rays and heat; these factors seem to be related to infertility in both sexes. Several studies of apoptosis on male infertility establish an association between increased cell death and fertility problems. Actually, an increase in apoptotic germ cells in testis of patients suffering severe oligozoospermia and azoospermia has been reported (Lin et al., 1997).

$\mathrm{Li}$ and co-workers reported that BID, a pro-apoptotic Bcl-2 family member, is a specific substrate of caspase- 8 in the Fas apoptotic signaling pathway. While non-truncated BID is localized in cytosol, truncated BID (tBID) translocates to mitochondrial outer membrane and thus transduces extracellular apoptotic signals to mitochondria. tBID induces release of cytochrome $c$, loss of mitochondrial membrane potential, cell shrinkage, and nuclear condensation in a caspase-dependent fashion. Thus, BID is a mediator of mitochondrial damage induced by caspase-8 (Li et al., 1998).

\subsection{Intrinsic apoptosis}

Apart from the extrinsic pathway, intrinsic apoptosis is also involved in both physiological and pathological processes. The anti-apoptotic Bcl-2 family members play a critical role in the intracellular balance, likely hormonally-controlled, determining which cell lives or which one dies (Rodríguez, 1997). As mentioned before, apoptosis is present in the normal human testis involving all classes of germ cells. In this regard, Oldereids reported that there was a preferential expression of Bax, Bcl-xL, Bcl-2, Bad and Bak in germ cell compartments suggesting that these apoptotic proteins are involved in differentiation and maturation through the various stages of human spermatogenesis (Oldereid et al., 2001), under intrinsic apoptosis control. During the male embryo development, primordial germ cells migrate from allantoids, where they are generated to develope gonads, known as gonadal ridge. In this process apoptosis occurs in order to eliminate cells with anomalous migration, which therefore would be cause of physiological anomalies. Redundant primordial germ cells are controlled by the balance of Bcl-xL and Bax proteins, which determine the death or survival process. Thus, in case of cell death, apoptosis is carried out affecting permeability of mitochondria and their subsequent collapse (Rucker et al., 2000). 
According to recent studies, hormones control apoptosis in different stages of maturity. Follicle-stimulating hormone (FSH) and testosterone play a role predominantly acting as survival factors. Studies to test the action of testosterone showed that the hormone influence, at least in rodents, is exercised through both pathways, intrinsic and extrinsic, in spermatocytes and spermatids. Studies in gonadotrophin-deficient men suggest that the hormonal control on apoptosis of spermatogonia is exercised through the intrinsic pathway (Rawanpura et al., 2008).

Experimental evidence have shown that mitochondrial membrane potential $\left(\Delta \Psi_{\mathrm{m}}\right)$ could be used as a trustable tool to determine the sperm quality, given that the $\Delta \Psi_{\mathrm{m}}$ and sperm functions are correlatively related. For instance, studying JC-1 staining, a probe sensitive to $\Delta \Psi_{\mathrm{m}}$, it was observed a relationship with events such as compromise plasma membrane permeability (Troiano et al., 1998), DNA damage (Donelli et al., 2000), motility and in vitro fertilization rates (Marchetti et al., 2004) or even presence of phosphatidylserine (Barroso et al., 2006). In all cases, a correlation between sperm quality and $\Delta \Psi_{\mathrm{m}}$ could be found. This suggests that $\Delta \Psi_{\mathrm{m}}$ may be used as a diagnosis of dysfunctional spermatozoa suffering from apoptotic process, low motility, DNA damage or other types of undesirable occurrences. In this way, the rates of pregnancy among barren couples could be easily improved when abnormal sperm is discarded. Interestingly, those spermatozoa showing high $\Delta \Psi_{\mathrm{m}}$ have shown intact functionality of acrosome as well as high motility values and fertilizing capacity (Gallon et al., 2006). Likewise, low $\Delta \Psi_{\mathrm{m}}$ is related to low rates of pregnancy (Marchetti et al., 2004). Together, these results suggest the importance of mitochondrial functionality for fertilizing capacity of human spermatozoa.

The use of chemotherapeutic agents leads to undesirable consequences on sperm functionality, damaging DNA and/or triggering apoptosis affecting mitochondria. For instance, betulinic acid (BA) has been shown to disrupt $\Delta \Psi_{\mathrm{m}}$, activating subsequently caspase-9 and -3 . These events of intrinsic programmed cell death have been related to a significant decrease of spermatozoa motility (Dathe et al., 2005), given that they induce apoptosis through mitochondria, the cell energy source necessary for sperm motility or velocity. Pre-incubation of spermatozoa with z-VAD-fmk inhibited only in a partial way the loss of $\Delta \Psi_{\mathrm{m}}$ under BA treatment, which is indicative that BA-induced mitochondrial disruption is independent of caspase activation (Espinoza et al., 2009). Together these results suggest that inducers of the mitochondrial pathway of apoptosis applied in the treatment of cancer affect directly to men fertility. High $\Delta \Psi_{\mathrm{m}}$ has been positively correlated to sperm concentration and negatively to levels of ROS. This is consistent with low rates of in vitro fertilization (IVF) (Wang et al., 2003). Controversially, the anticancer agent cisplatin is able to induce caspase- 8 and apaf- 1 , activating caspase- 3 and -2 even with caspase- 9 blocked. This implies that cisplatin leads to apoptosis independently of mitochondria (Muller et al., 2003).

Hyperthermia is the base for cryptorchidism. Exposure of germ cells at mild heat results in induction of apoptosis. Besides FasL, Bax translocation to mitochondria, caspases-3, -6, -9, -7 activation and cytochrome $c$ release have been detected under hyperthermia treatment. However, heat-induced apoptosis in FasL-defective cells was not blocked. These results demonstrate that heat-induced apoptosis occurs via mitochondria (Said et al., 2004).

Alkylating drugs against cancer such as cyclophosphamide (CP) have unwanted results in patients' germ cells, both in seminogram parameters and in causing DNA damage as a consequence. However, it has been described that these unwanted effects could be mitigated 
by the presence of antioxidants, e.g. astaxanthin, a red carotenoid pigment (Tripathi \& Jena, 2008). Genotoxicity of different anti-neoplastic agents, including methotrexate or tamoxifen, induces hazards in both somatic and germ cells, as a consequence of cancer treatment side effects. However, pretreatment with the antioxidant taurine alleviates chromosomal aberrations, and restores GSH levels, increasing the count and motility of spermatozoa and decreasing abnormalities (Allam et al., 2011).

\section{ROS generation and oxidative stress}

Aerobic organisms are continuously exposed to ROS. The main source of ROS is the electron transport chain within the inner mitochondrial membrane. Apoptosis can also be stimulated by ROS in several cell types (Brookes et al., 2004; Bejarano et al., 2008; Lozano et al., 2009). Aerobic cells are equipped with the necessary antioxidant machinery to scavenge ROS and keep free radicals at homeostatic levels avoiding pathological effects due to oxidative stress. It has been long recognised that ROS may form an important link similar to the second messenger intracellular communication, or even taking part in physiological processes such as "the respiratory burst" in macrophages or neutrophils. Nevertheless, physiological levels of ROS are also required for normal sperm functions including hyperactivation, capacitation and acrosome reaction (Sikka et al., 1995). The amount of scavenging enzymes of spermatozoa is limited as well as their cytoplasm, in which these enzymes are found, making them highly susceptible to ROS damage. Actually, it has been suggested that the damage to the acrosome membrane may not be related to sperm motility (Griveau et al., 1995). Lipid peroxidation caused by oxidative stress conditions during the transport of sperm through the epididymis not only affects the plasma membrane of these cells in close contact with each other during transport, but can also inhibit the acrosome reaction by damaged acrosome membrane with no apparent effect on motility (Oehninger et al., 1995).

When global levels of ROS, overcome the available total antioxidant capacity (TAC) oxidative stress occurs, which results in oxygen and oxygen-derived oxidants. Given that ROS are able to readily permeate membranes, within cells, DNA, proteins and lipids suffer from oxidative damage, leading cells into apoptosis. ROS present in seminal plasma can be originated from several sources, both endogenous and exogenous. The ejaculated semen is made up of different types of cells, including mature and immature spermatozoa, leukocytes and epithelial cells, being leukocytes and immature spermatozoa the major source of ROS (Kothary et al., 2010). Leukocytes, more specifically neutrophils and monocytes, are present in semen, avoiding the presence of pathogens. In line with this, during infection leukocytes produce high amount of ROS (Tremellen et al., 2008). A detrimental activity of superoxide dismutase (SOD) and increased levels of proinflammatory interlekin- 8 can also be detected (Blake et al., 1987). Semen contains antioxidants that protect germ cells from environmental oxidative hazard. However, antioxidants are removed by assisted reproductive techniques, leaving sperm cells especially vulnerable to oxidative damage. Semen manipulation, like cryopreservation or repeated cycles of centrifugation, has unwanted effects on germ cells. After cryopreservation and thawing or centrifugation, an excess of ROS is detected evoking oxidative stress in germ cells due to lowered intracellular antioxidant levels. As expected, these effects cause irreversible damage to DNA (Agarwal et al., 1994; Kumar et al., 2011). In this regard, the application of antioxidants appears as a tool to protect germ cells from manipulation- 
induced oxidative damage. Growing studies support the beneficial effect of antioxidants. For example, the exposure of post-thawed spermatozoa showing increased levels of ROS to ascorbate or catalase reduced ROS production and subsequent apoptotic events, such as loss of $\Delta \Psi_{\mathrm{m}}, \mathrm{PI}$ and Annexin $\mathrm{V}$ staining. Moreover, a considerable improvement in sperm parameters was also appreciated (Li et al., 2010). Similar results were obtained with other antioxidants like cystein, taurine, chloropromazine, and treating samples with the antioxidant enzymes SOD and glutathione peroxidease (Paudel et al., 2010; Thuwanut et al., 2010). The use of melatonin, which has an uncommomly low toxicity profile, has been also proposed as a powerful antioxidant and anti-apoptotic agent in ejaculated human spermatozoa (Espino et al., 2010).

Apart from leukocytes, immature spermatozoa are an additional source of ROS. Erroneous spermatogenesis does not allow the regular extrusion of cytoplasm from potential germ cells for maturation process. Thus, these sperm cells contain an excess of cytoplasm and are considered immature (teratozoospermic). The excess activates the NADPH system (Kothary et al., 2010), mainly in mitochondria, resulting in an increase of free radicals. Moreover, mitochondria have been reported to be the main source of ROS in infertile men (Plante et al., 1994). It has been reported a positive tendency between teratozoospermia and ROS production at pathological levels, as well as apoptosis and DNA damage in spermatozoa (Sikka et al., 1995). In this regard, it has been reported that $\mathrm{H}_{2} \mathrm{O}_{2}$-evoked oxidative stress induces mitochondrial ROS generation affecting mitochondria functionality and activating caspase-9 in human spermatozoa (Espino et al., 2010). Caspase-9 is an initiator protease considered to be involved in the initial steps of mitochondrial apoptosis. The pre-incubation of spermatozoa with the specific inhibitor of caspase-9, z-LEHD-fmk, was able to block $\mathrm{H}_{2} \mathrm{O}_{2}$-evoked caspase-3 activation (Bejarano et al., 2008). Taken together, these findings strongly suggest that oxidative stress leads cells into apoptosis through the mitochondrial pathway. Evidence suggests that ROS-mediated damage to sperm significantly contributes to $30-80 \%$ of pathological cases (Shekarriz et al., 1995; Agarwal et al., 2006).

Natural antioxidants including melatonin are currently acquiring great importance for cell protection against oxidative hazards. Melatonin reduces calcium-evoked ROS generation, as well as caspase-9, what means that melatonin protects mitochondria, blocking the apoptotic process (Espino et al., 2010). Similarly, myo-inositol, the most important form in nature of inositol, a component of vitamin B, has been suggested to have an antioxidant seminal action. Particularly, myo-inositol has shown capacity to ameliorate mitochondrial function of oligo-astheno-theratozoospemic patients. This indicates that the molecule may be used for the treatment against male infertility (Condorelli et al., 2011). ROS cause infertility by two main mechanisms. First, ROS damage the sperm membrane which in turn reduces the sperm motility and ability to fuse with the oocyte. Second, ROS directly damage sperm DNA, compromising the paternal genomic contribution to the embryo (Tremellen et al., 2008). A positive correlation between urinary TAC and different seminogram parameters including concentration, motility, morphology and vitality, as well as a negative correlation with round cells has been shown (Ortiz et al., 2011). Hence, antioxidant endogenous levels strengthen or ameliorate sperm parameters and diminish the number of round cells, which are responsible, at least in part, for the oxidant environment in seminal fluid due to ROS generation. Also endogenous melatonin exerts a role in semen quality improvement. Additionally, evidence supports that melatonin supplementation has a potential use to obtain more successful assisted reproductive technique outcomes (Ortiz et al., 2011.). 
Although, orally-administered antioxidants improve sperm DNA damage and protamine packaging, and reduce seminal ROS generation and apoptosis, other researchers have not observed significant changes in routine sperm parameters (concentration, motility and morphology) (Tunc et al., 2009).

Infection in the genital tract usually results in leukocyte increase and a subsequent elevation of seminal ROS levels. If the number of leukocytes exceeds normality $\left(1 \times 10^{6}\right.$ leukocytes $\left./ \mathrm{mL}\right)$ spermatozoa integrity may be compromised. However, at lower concentrations, leukocytes occasionally may cause oxidative stress (Kothary et al., 2010). Varicocele has adverse effects on spermatogenesis and sperm quality, but the responsible mechanisms remain little known. High levels of ROS, as well as low TAC levels, have been detected in semen from infertile varicocele patients and a decrease in ROS levels has been shown after varicocelectomia (Agarwal et al., 2004). ROS presence plays an important role causing asthenozoospermia. Given that some reactive species can induce peroxidation on membrane lipids, they affect negatively to axonemal structures compromising severely the sperm motility and the asthenozoospermia occurs. Interestingly, most men suffering from spinal cord injury suffer also from infertility (Lisenmeyer \& Perkash, 1991). Both a polluted environment or lifestyle habits are quite often the causal origin of presence of ROS in sperm. Not only industrial air pollutants, such as those included in beauty products, heavy metals, pesticides, sulfur dioxide or food preservatives (Kothary et al., 2010), but also compounds of cigarette smoke have been reported to be harmful for health. More specifically, cigarette smoke produces ROS and decreases TAC and semen parameters (Saleh et al., 2002). In line with this, it is noteworthy that smokers' semen contains more ROS than non-smokers' semen. Thereby, fertility might be compromised by smoking-derived effects. Moreover, ethanol consumption may also have adverse effects for male fertility. Ethanol metabolism induces ROS generation damaging cellular molecules, including DNA, proteins and lipids (Vine, 1996). Given that antioxidant defenses play an essential role in apoptosis regulation, even when the death signal is not oxidative stress, supplementation which antioxidants, such as $\mathrm{N}$-acetyl-Lcystein, both in vitro and in vivo, may diminish DNA-damage of spermatozoa, suggesting a new therapeutic strategy for oligospermic patients (Erkkilä et al., 1998).

Generally there are some anomalies in DNA of ejaculated spermatozoa. However the consequences that fertilization with anomalous DNA could cause in the development of the embryo are still not very well known. Intracytoplasmic sperm injection appears to be a growing risk to transfer damaged DNA (Sakkas et al., 1999b). In this regard, further studies are necessary to identify and select sperm with undamaged DNA or remove sperm with damaged DNA from samples, in order to improve the efficiency of pregnancy with in vitro fertilization methods. Although there is a negative correlation between quality of sperm parameters and DNA damage, breaks in DNA have been also found in normal parameters of seminograms. Two hypotheses define the most likely explanation for DNA damage in spermatozoa, a failed packaging of chromatin and induction of apoptosis (for review see Sakkas et al., 1999b). The main origin of DNA damage can be found in the anomalous packaging of chromatin. Protamines are proteins in charge of the DNA packaging, replacing histones in the haploid spermatogenesis. Furthermore they are believed to be essential for sperm condensation and DNA stabilization. Protamines are usually deficiently deposited in DNA during the packaging of spermatogenesis, remaining some vulnerable nicks along the chromatin. These nicks indicate incomplete maturation during spermatogenesis. Thus, DNA is susceptible to suffer damage by ROS or nucleases, which is in agreement with findings 
that showed a correlation between DNA damage and a deficient packaging due to underprotamination (Sailer et al., 1995). The tumor suppressor protein p53 is expressed when DNA is damaged. p53 promotes the transcription of some genes involved in apoptosis, including those that code for death receptors and pro-apoptotic Bcl-2 (Müller et al., 1998). Although p53 is not found in normal spermatogenesis, it has been found in spermatogonia under X-ray treatment, since germ cells from p53 knockout mice are not prone to trigger apoptosis of germ cells when DNA is irradiated. Evidence suggests that p53 is particularly involved at removing lethally damaged spermatogonia (Beumer et al., 1998).

\section{Role of $\mathrm{Ca}^{2+}$ in sperm physiology}

Cytosolic $\mathrm{Ca}^{2+}$ signals can control several physiological processes in excitable and nonexcitable cells. These signals are produced by opening channels permeable to $\mathrm{Ca}^{2+}$ either in the plasma membrane or in the membrane of intracellular organelles containing high $\mathrm{Ca}^{2+}$ concentrations. $\mathrm{Ca}^{2+}$-permeable channels can catalyze the flow of millions of $\mathrm{Ca}^{2+}$ ions through non-conducting lipid bilayers and, therefore, a small number of channels can cause significant changes in a tiny cell, such as the sperm, within milliseconds. In fact, changes in the intracellular concentration of $\mathrm{Ca}^{2+}$ due to the activation of such channels have been associated with different aspects of mammalian sperm function, including sperm motility, capacitation and the acrosome reaction.

\subsection{Sperm capacitation}

Capacitation of sperm is a prerequisite for successful fertilization. It comprises a series of complex and finely tuned changes that normally occur during transit in the female genital tract so that spermatozoa can reach and fuse with the oocyte. Changes associated with this process comprise, among others, an increase in respiration and subsequent changes in the sperm motility pattern, removal of cholesterol from the plasma membrane, increases in $\left[\mathrm{Ca}^{2+}\right]_{\mathrm{i}}$ in the sperm head and flagellum, and activation of second-messenger cascades (de Lamirande et al., 1997; Purohit et al., 1999; Darszon et al., 2001). Importantly, the most significant change in sperm after capacitation is its ability to undergo the acrosome reaction $(\mathrm{AR})$.

Ion environment and ion fluxes through the sperm plasma membrane are highly important in capacitation. Particularly, intracellular $\mathrm{Ca}^{2+}$ has been shown to be increased during capacitation. This may be the result of (i) reduced $\mathrm{Ca}^{2+}$ efflux due to inhibition of the $\mathrm{Ca}^{2+}$ ATPase pump, (ii) increased leakage of $\mathrm{Ca}^{2+}$ across the membrane owing to instability caused by removal of cholesterol, and/or (iii) increased $\mathrm{Ca}^{2+}$ influx due to the activation of unidentified channels (Jagannathan et al., 2002). Nevertheless, regulation of voltage-gated $\mathrm{Ca}^{2+}(\mathrm{Cav})$ channels during sperm capacitation may also occur, although such a regulation has not been directly established (Espinosa et al., 2000; Darszon et al., 2001).

\subsection{The acrosome reaction}

The sperm acrosome reaction (AR) is a fundamental reproductive strategy which is a prerequisite for successful fertilization. It involves exocytosis of the acrosomal vehicles contained in the head of the sperm. During this process, lytic enzymes and materials required for sperm binding are released into the extracellular space leading to the fusion of 
the gametes. $\mathrm{Ca}^{2+}$ influx is an absolute requirement for the physiological AR in sperm from all species examined to date (Vansudevan et al., 2010). In mammals, fertilization begins with the direct interaction of sperm and egg, a process mediated primarily by gamete surface proteins. Once the sperm has penetrated the cumulus cells and reaches the zona pellucida (ZP), it undergoes exocytosis, thus releasing the acrosomal content.

Sperm-ZP adhesion activity has been confirmed by gene knockout of one sperm surface enzyme that putatively binds ZP3 (a glycoprotein constituent of the ZP), i.e. beta-1,4galactosyltransferase I (GalT I) (Rodeheffer \& Shur, 2004). ZP3-induced exocytosis of the acrosomal contents proceeds through two sperm signaling pathways. In the first, ZP3 binding to GalT I and other potential receptors results in activation of a heterotrimeric guanosine-5'-trisphosphate (GTP)-binding protein and phospholipase C (PLC), thus elevating the concentration of intracellular $\mathrm{Ca}^{2+}$. In the second pathway, ZP3 binding to the same receptor(s) stimulates a transient influx of $\mathrm{Ca}^{2+}$ through T-type $\mathrm{Ca}_{\mathrm{V}}$ channels. The intracellular $\mathrm{Ca}^{2+}$ signal elicited by $\mathrm{ZP3}$ is prolonged and the sperm AR occurs some minutes after the beginning of this signal. This initial intracellular $\mathrm{Ca}^{2+}$ entry, in a later phase of the signaling, induces a second, sustained $\mathrm{Ca}^{2+}$ influx through transient receptor potential cation (TRPC) family $\mathrm{Ca}^{2+}$ channels, thereby resulting in a sustained increase in intracellular $\mathrm{Ca}^{2+}$ that triggers exocytosis (Darszon et al., 2001; Primakoff and Myles, 2002).

\subsection{Sperm motility}

Although the external triggering mechanisms that initiate sperm motility are largely unknown, evidence supports a modification of the $\mathrm{Ca}^{2+}$ balance by several separate mechanisms. Elevation of intracellular $\mathrm{Ca}^{2+}$ can occur by entry of $\mathrm{Ca}^{2+}$ ions into cells through the plasma membrane or release of $\mathrm{Ca}^{2+}$ from internal stores. At this respect, it has been demonstrated that $\mathrm{Ca}_{\mathrm{V}}$ channels are expressed in the sperm tail and may participate in the regulation of flagellar motility. Thus, these channels are present in the sperm flagella and compounds known to inhibit them induce a small decrease in human sperm motility, thereby indicating they might participate in regulating this function (Trevino et al., 2004). Additionally, confocal immunofluorescence experiments have shown that, at least, four distinct types of capacitative $\mathrm{Ca}^{2+}$ channels (TRPC1, 3, 4 and 6) are expressed and differentially localized in the human sperm. By analyzing the effects of distinct TRPC channel antagonists using a computer-assisted assay, evidence suggests that these proteins may play an important role in controlling human sperm flagellar movement (Castellano et al., 2003).

Likewise, at some time before fertilization, mammalian sperm undergoes a change in movement pattern, named hyperactivation, which is critical to the success of fertilization because it enhances the ability of sperm to penetrate the egg's ZP (Ho \& Suarez, 2001a,b). Experimental evidence suggests that hyperactivated motility may be regulated by an inositol 1,4,5-trisphosphate receptor $\left(\mathrm{IP}_{3} \mathrm{R}\right)$-gated intracellular $\mathrm{Ca}^{2+}$ store in the neck region of mammalian sperm (Ho and Suarez, 2001b). Moreover, the unique sperm-specific cation channel, CatSper, is expressed by meiotic and post-meiotic spermatogenic cells but not by other cells, and is present in the sperm flagellum, thus suggesting a role in the regulation of sperm motility. In line with this, targeted disruption of mouse CatSper gene results in male sterility, mainly due to the inability of sperm to maintain normal patterns of motility and to penetrate the egg's ZP (Ren et al., 2001). Actually, disruption of CatSper2 seems to underlie 
highly reduced sperm motility in man, as ascertained in asthenoteratozoospermic patients (Avidan et al., 2003), which constitutes the first description of an autosomal gene associated with non-syndromic male infertility in humans.

\subsection{Sperm apoptosis and its interaction with $\mathrm{Ca}^{2+}$ signaling}

Apoptosis signaling in human sperm has been a controversially debated issue for a long time, because sperm are mainly transcriptionally inactive cells (Grunewald et al., 2005) and the knowledge gained from studies of somatic cells cannot be transferred without experimental evidence. Although initial studies denied the presence of apoptosis in ejaculated human sperm at all (Weil et al., 1998), and further studies suggested an abortive apoptosis as a remnant of incomplete spermatogenesis (Sakkas et al., 1999a), recent publications have suggested that human spermatozoa have the ability to undergo apoptosis or apoptosis-like conditions in response to a variety of stimuli (Grunewald et al., 2001; Paasch et al., 2003, Taylor et al., 2004; Eley et al., 2005; Barroso et al., 2006; Martin et al., 2007; Bejarano et al., 2008; Espino et al., 2011). Apoptosis signaling in human sperm is preferentially based on the mitochondria-associated pathway, the main features being activation of the initiator caspase, caspase-9, disruption of the transmembrane mitochondrial potential, activation of the major effector caspase, caspase-3, and consecutive cellular degradation (Paasch et al., 2004; Bejarano et al., 2008).

Although calcium is a key regulator of cell survival, the sustained and prolonged elevation of $\left[\mathrm{Ca}^{2+}\right]_{i}$ plays a role in cell death (Demaurex \& Distelhorst, 2003). The pro-apoptotic effects of calcium are mediated by a diverse range of calcium-sensitive factors that are compartmentalized in various intracellular organelles, including endoplasmic reticulum and mitochondria (Hajnoczky et al., 2003). Excessive calcium load to the mitochondria may induce apoptosis by stimulating the release of apoptosis-promoting factors from the mitochondrial intermembrane space to the cytosol and by impairing mitochondrial function (Wang, 2001). In this context, it has been demonstrated that $\mathrm{H}_{2} \mathrm{O}_{2}$ and progesterone are able to induce a mitochondria-dependent apoptosis program in ejaculated human spermatozoa, which requires increases in intracellular $\mathrm{Ca}^{2+}$ concentration and $\mathrm{Ca}^{2+}$ entry into mitochondria. In fact, both the $\left[\mathrm{Ca}^{2+}\right]_{i}$ chelator, dimethyl BAPTA, and the specific blocker of calcium uptake into mitochondria, Ru360, were able to inhibit sperm apoptosis induced by both $\mathrm{H}_{2} \mathrm{O}_{2}$ and progesterone, as ascertained by experiments on caspase- 3 activity and phosphatidylserine externalization (Bejarano et al., 2008).

Bcl-2 family members are reported to have an important role during testicular development (Yan et al., 2000). The members of the Bcl-2 family, composed of both death agonists and antagonists, differ in their structural features, and their expression pattern depends on the tissue of expression (Reed, 1997). A homologue of Bcl-2, Bcl-x, exists in two isoforms generated by alternative splicing. The large form, Bcl-xL, protects cells against death, whereas the short form, Bcl-xS, promotes cell death by inhibiting Bcl-2 or Bcl-xL function. In this context, it has been suggested that ionic alterations in the cell could signal a change in alternative splicing of Bcl-x leading to up-regulation of a given isoform. Thus, by using a well-known testicular toxin, 2,5-hexanedione (2,5-HD) (Akingbemi \& Hardy, 2001), it has been proven that exposure to $2,5-\mathrm{HD}$ causes an intracellular $\mathrm{Ca}^{2+}$ increase in spermatogenic cells, thus producing a shift toward a relative increase of Bcl-xS encoding isoform over the $\mathrm{Bcl}-\mathrm{xL}$ isoform. Since the level of Bcl-2 and Bax remained unchanged after 2,5-HD exposure, 
the effect of 2,5-HD seems to be mediated by reversal of the ratio between apoptosisinducing and -preventing isoforms of Bcl-x, leading to mitochondrial changes resulting in apoptotic death (Mishra et al., 2006). On the other hand, the Fas/FasL system has been strongly implicated in spermatogenic cell death during development (Hikim et al., 2003), adulthood (Koji et al., 2001), and after toxin exposure (Richburg et al., 2000). Actually, it has been showed that physiological apoptosis of spermatocytes during the first wave of spermatogenesis is associated with Fas up-regulation. Interestingly, up-regulation of Fas and subsequent activation of caspases were correlated with an increase in intracellular $\mathrm{Ca}^{2+}$ concentration (Lizama et al., 2007), thereby reaffirming the notion that apoptosis is linked to alterations in $\mathrm{Ca}^{2+}$ homeostasis.

\section{Melatonin, a new advantage in fertility}

Melatonin (N-acetyl-5-methoxytryptamine), the main secretory product of the pineal gland, acts as an antioxidant and a "scavenger" of free radicals, possesses anti-proliferative, oncostatic and anti-aging activity, and immunomodulatory and neuroprotective effects. Other organs and tissues can also produce melatonin, where it can be found in high concentrations. At the level of subcellular organelles, melatonin levels may vary. Some authors have reported levels of melatonin in the nucleus and mitochondria higher than those found in plasma (León et al., 2004). The number of articles reporting the role of melatonin in apoptosis has dramatically increased in the last decade. The fields of interest are grouped into two categories: i) the role of melatonin in preventing apoptosis in normal cells and ii) the role of melatonin increasing apoptosis in cancer cells. This pro-apoptotic role in tumor cells contrasts sharply with the anti-apoptotic actions in normal cells, implying a potential use of melatonin in the death of tumor cells, thus preserving cellular function of normal cells (Sainz et al., 2003; Bejarano et al., 2011).

It is known that human seminal plasma contains melatonin, which can exert important effects on sperm motility and sperm function, favoring and increasing fertility rates. In fact, it has been shown that melatonin is able to increase sperm hyperactivation acting through its receptor MT1 (Fujinoki, 2008). Melatonin also exerts beneficial effects in oocyte physiology and improves the fertilization rate. This means that melatonin has potential beneficial effects on fertility, for both male and female. It is worth noting that the supplementation with melatonin may be especially important in couples where one or both may be infertile. However, few clinical trials have been carried out in infertile patients treated with melatonin at medium/long-term periods.

Melatonin is known to regulate seasonal and circadian rhythms in mammals (Reiter et al., 2009), but emerging evidence also suggests that melatonin possesses protective effects against free radicals and apoptosis. This also seems to be the case for its metabolites (Hardeland et al., 2009). Results clearly indicate that the urinary metabolite of melatonin, 6sulfatoxymelatonin is highly positively correlated with sperm quality, determined as sperm concentration, morphology, and sperm motility (Ortiz et al., 2010), while negatively correlated with round cells present in the ejaculate. The action of the indoleamine after the induction of apoptosis in human sperm using $\mathrm{H}_{2} \mathrm{O}_{2}$ and progesterone has been analyzed, reaching the conclusion that the use of melatonin inhibits the production of ROS and reverses various characteristics of apoptosis such as caspase activation or phosphatidylserine externalization (Espino et al., 2010). Antioxidant and detoxifying 
properties of melatonin have stimulated studies showing a reduction in molecular damage. In relation to this, the protective role of melatonin against oxidative damage and apoptosis in ejaculated human spermatozoa, as a result of its free radical scavenger action, has been recently reported (Espino et al., 2010).

This anti-apoptotic effect of melatonin is directly related to its known antioxidant capacity. Anti-apoptotic effects of melatonin are dose dependent, and depend on the activation of membrane receptor MT1. Moreover, the protective actions of melatonin on apoptosis induced by oxidative stress with $\mathrm{H}_{2} \mathrm{O}_{2}$ or $\left[\mathrm{Ca}^{2+}\right]_{\mathrm{i}}$ overload evoked by progesterone appears to be dependent on protein kinases ERK, which are related to cell survival (Espino et al., 2011). In addition, a recent study showed that melatonin and TAC nocturnal levels are positively correlated with several seminal parameters, including sperm concentration, motility and morphology, and negatively correlated with number of round cells present in seminal samples (Ortiz el al., 2011). An improvement in the in vitro sperm motility when spermatozoa are incubated for short periods of time with pharmacological concentrations of melatonin has been shown (Ortiz et al., 2011). The influence that the neurotransmitter serotonin (melatonin precursor) may have on seminal parameters, has been also determined through its urinary metabolite, 5-hydroxyindoleacetic acid in men with working rotating shifts, confirming that a mismatch in levels of serotonin may negatively affect the reproductive capacity of patients (Ortiz et al., 2010). Taken together, these results may contribute to a better understanding of the physiology and genesis of the pathological processes that affect human sperm, for example in asthenozoospermia or oligozoospermia, facilitating the establishment of guidelines and/or therapies for conditions related to human sperm, and by extension for the male reproductive physiology.

\section{Conclusion}

Although the relevance of understanding the mechanisms that control germ cell death is evident, male infertility treatment requires further investigation. Apoptosis is a wellcharacterized mechanism for removing redundant cells. The characterization of several apoptotic events as critical signals in damaged cells symbolizes a key advance in the knowledge of molecular aspects of male infertility. Detection of ROS overproduction is a faithful indicator of impaired spermatozoa. Seminal parameters including motility, morphology, velocity, concentration, and presence of rounds cells are closely related to oxidative status of germ cells. In fact, ROS damage DNA directly and indirectly triggering apoptosis, which subsequently leads to degradation of cellular substrates. Since imbalanced presence of ROS is common in many infertility-related disorders, antioxidant treatments are becoming relevant in protecting male germ cells from intracellular damage, increasing fertilization success rates. Additionally, sperm showing normal parameters experience an increase in ROS levels after manipulation, which decreases its quality. As discussed herein, antioxidants protect from damage caused when sperm is manipulated. On the other hand, Fas is present in plasma membrane of undesirable cells. Its expression may therefore help to localize immature spermatocytes or damaged germ cells. However, current fertilization techniques do not test this condition in spermatozoa. Cytometry sorting could help to rule out spermatozoa that show a positive profile for both Fas and ROS generation. In vitro fertilization techniques should take into account these hazardous signals to discard damaged spermatozoa that in normal conditions would have been eliminated. Knowledge 
on the effect of fertilization carried out with undesirable spermatozoa in embryo development still remains vague and controversial. Studies focused not only on seminogram parameters but also on the relationship between physiological status or apoptotic events and sperm quality are needed. Melatonin is an innocuous and antioxidant molecule that improves semen quality. Its supplementation may be potentially used to obtain successful results when assisted reproductive techniques are used. Further studies are required to clarify molecular mechanisms responsible for the beneficial effects of melatonin and to test whether the supplementation with the indoleamine is feasible to increase success rates in assisted reproductive technology.

\section{Acknowledgement}

This study was supported by Angelini Farmaceutica S.A. and Ministerio de Ciencia e Innovación-Fondo Europeo de Desarrollo Regional (BFU2010-15049). I. Bejarano is a beneficiary of a grant from Angelini Farmaceutica SA. S.D. Paredes was a beneficiary of a grant from Consejería de Economía, Comercio e Innovación-Fondo Social Europeo (Junta de Extremadura REI09009). J. Espino is a beneficiary of a grant from Ministerio de Ciencia e Innovación (AP2009-0753). The authors would like to express their thanks to Servicio de Técnicas Aplicadas a las Biociencias (STAB) of University of Extremadura for their excellent technical assistance.

\section{References}

Agarwal, A.; Ikemoto, I. \& Loughlin, K.R. (1994) Relationship of sperm parameters with levels of reactive oxygen species in semen specimens. The Journal of urology. Vol.152, No.1, pp.107-110, ISSN 0022-5347.

Agarwal, A.; Nallella, K.P.; Allamaneni, SS. \& Said, T.M. (2004). Role of antioxidants in treatment of male infertility: an overview of the literature. Reproductive Biomedicine. Vol.8, No.6, pp.616-627, ISSN 1472-6483.

Agarwal, A.; Prabakaran, S. \& Allamaneni, S. (2006). What an andrologist/urologist should know about free radicals and why. Urology. Vol.67, No.1, pp.2-8, ISSN 00904295.

Aitken, R.J. \& Curry, B.J. (2011). Redox regulation of human sperm function: from the physiological control of sperm capacitation to the etiology of infertility and DNA damage in the germ line. Antioxidants E redox signaling. Vol.14, No.3, pp.367-381, ISSN 1523-0864.

Aitken, R.J. \& Koppers, A. (2011). Apoptosis and DNA damage in human spermatozoa. Asian journal of andrology. Vol.13, No.1, pp.36-42, ISSN 1008-682X.

Akingbemi, B.T. \& Hardy, M.P. (2001). Oestrogenic and antiandrogenic chemicals in the environment: effects on male reproductive health. Annals of medicine Vol.33, No.6, pp.391-403, ISSN 0785-3890.

Alam, S.S.; Hafiz, N.A. \& Abd El-Rahim, A.H. (2011) Protective role of taurine against genotoxic damage in mice treated with methotrexate and tamoxfine. Environmental toxicology and pharmacology. Vol.31, No.1, pp.143-152, ISSN 1382-6689.

Allison, J.; Georgiou, H.M.; Strasser, A. \&Vaux, D.L. (1997). Transgenic expression of CD95 ligand on islet beta cells induces a granulocytic infiltration but does not confer 
immune privilege upon islet allografts. Proceedings National Academy of Sciences of United States of America. Vol.94, No.8, pp.3943-3947, ISSN 0027-8424.

Avidan, N.; Tamary, H.; Dgany, O.; Cattan, D.; Pariente, A.; Thulliez, M.; Borot, N.; Moati, L.; Barthelme, A.; Shalmon, L.; Krasnov, T.; Ben-Asher, E.; Olender, T.; Khen, M.; Yaniv, I.; Zaizov, R.; Shalev, H.; Delaunay, J.; Fellous, M.; Lancet, D. \& Beckmann, J.S. (2003). CATSPER2, a human autosomal nonsyndromic male infertility gene. European Journal Human Genetics. Vol.11, No.7, pp. 497-502, ISSN 1018-4813.

Baker, T.G. (1963). A quantitative and cytological study of germ cells in human ovaries. Proceedings of the royal society of london. Series b, biological sciences. Vol.158, pp.417433, ISSN 0080-4649.

Barroso, G.; Taylor, S.; Morshedi, M.; Manzur, F.; Gavino, F. \& Oehninger, S. (2006). Mitochondrial membrane potential integrity and plasma membrane translocation of phosphatidylserine as early apoptotic markers: a comparison of two different sperm subpopulations. Fertility and Sterility. Vol.85, No.1, pp.149-154, ISSN 00150282.

Barroso, G.; Taylor, S.; Morshedi, M.; Manzur, F.; Gaviño, F. \& Oehninger, S. (2006). Mitochondrial membrane potential integrity and plasma membrane translocation of phosphatidylserine as early apoptotic markers: a comparison of two different sperm subpopulations. Fertility and sterility. Vol.85, No.1, pp.149-154, ISSN 00150282 .

Bejarano, I.; Espino, J.; Marchena, A.M.; Barriga, C.; Paredes, S.D.; Rodríguez, A.B. \& Pariente, J.A. (2011). Melatonin enhances hydrogen peroxide-induced apoptosis in human promyelocytic leukaemia HL-60 cells. Molecular and cellular biochemistry. Vol.353, No.1-2, pp.167-176, ISSN 0300-8177.

Bejarano, I.; Lozano, G.M.; Ortiz, A.; Garcia, J.F.; Paredes, S.D.; Rodriguez, A.B.; Pariente, J.A.(2008). Caspase 3 activation in human spermatozoa in response to hydrogen peroxide and progesterone. Fertility and Sterility. Vol.90, pp.1340-1347, ISSN 00150282 .

Bellgrau, D.; Gold, D.; Selawry, H.; Moore, J.; Franzusoff, A. \& Duke, R.C. (1995). A role for CD95 ligand in preventing graft rejection. Nature. Vol.19, No.377, pp.630-632, ISSN 0028-0836.

Beumer, T.L.; Roepers-Gajadien, H.L.; Gademan, I.S.; Van Buul, P.P.; Gil-Gomez, G.; Rutgers, D.H. \& De Rooij, D.G. (1998). The role of the tumor suppressor p53 in spermatogenesis. Cell death and differentiation. Vol.5, No.8, pp.669-677, ISSN 13509047.

Blake, D.R.; Allen, R.E. \& Lunec, J. (1987). Free radicals in biological systems--a review orientated to inflammatory processes. British medical bulletin. ISSN 00071420.

Boumela, I.; Guillemin, Y.; Guérin, J.F. \& Aouacheria, A. (2009). The Bcl-2 family pathway in gametes and preimplantation embryos. Gynécologie, obstétrique \& fertilité. Vol.37, No.9, pp.720-732, ISSN 1297-9589.

Brookes, P.S.; Yoon, Y.; Robotham, J.L.; Anders, M.W. \& Sheu, S.S. (2004). Calcium, ATP, and ROS: a mitochondrial love-hate triangle. American journal of physiology. Cell physiology. Vol.287, No.4, pp.C817-C833, ISSN 0363-6143. 
Castellano, L.E.; Trevino, C.L.; Rodríguez, D.; Serrano, C.J.; Pacheco, J.; Tsutsumi, V.; Felix, R. \& Darszon, A. (2003).Transient receptor potential (TRPC) channels in human sperm: expression, cellular localization and involvement in the regulation of flagellar motility. FEBS Letter. Vol.541, No.1-3, pp.69-74, ISSN 0014-5793.

Celik-Ozenci, C.; Sahin, Z.; Ustunel, I.; Akkoyunlu, G.; Erdogru, T.; Korgun, E.T.; Baykara, M. \& Demir, R. (2006). The Fas system may have a role in male reproduction. Fertility and Sterility. Vol.85, No.1, pp.1168-78, ISSN 0015-0282.

Chandrasekaran, Y. \& Richburg, J.H. (2005). The p53 protein influences the sensitivity of testicular germ cells to mono-(2-ethylhexyl) phthalate-induced apoptosis by increasing the membrane levels of Fas and DR5 and decreasing the intracellular amount of c-FLIP. Biology of Reproduction. Vol.72, No.1, pp.206-213, ISSN 00063363.

Condorelli, R.A.; La Vignera, S.; Di Bari, F.; Unfer, V. \& Calogero, A.E. (2011). Effects of myoinositol on sperm mitochondrial function in-vitro. European review for medical and pharmacological sciences. Vol.15, No.2, pp.129-134, ISSN 1128-3602.

Darszon, A.; Beltrán, C.; Felix, R.; Nishigaki, T. \& Treviño, C.L. (2001). Ion transport in sperm signaling. Developmental of Biology. Vol.240, No.1, pp.1-14, ISSN 00121606.

Davis, J.S. \& Rueda, B.R. (2002). The corpus luteum: an ovarian structure with maternal insticts and suicidal tendencies. Frontiers in bioscience : a journal and virtual library. Vol.7, pp.d1949-d1978, ISSN 1093-9946.

De Lamirande, E.; Leclerc, P. \& Gagnon, C. (1997). Capacitation as a regulatory event that primes spermatozoa for the acrosome reaction and fertilization. Molecular Human. Reproduction. Vol.3, No.3, pp.175-194, ISSN 1360-9947.

De Vries, K.J.; Wiedmer, T.; Sims, P.J. \& Gazella, B.M. (2003). Caspase-independent expouse of aminophospholipids and tyrosine phosphorylation in bicarbonate responsive human sperm cells. Biology of Reproduction. Vol.68, No.6, pp. 2122-2134, ISSN 00063363 .

Demaurex, N. \& Distelhorst, C. (2003). Apoptosis-the calcium connection. Science. Vol.300, No.5616, pp.65-67, ISSN 0036-8075.

Donnelly, E.T.; O'Connell, M.; McClure, N. \& Lewis, S.E. (2000). Differences in nuclear DNA fragmentation and mitochondrial integrity of semen and prepared human spermatozoa. Human reproduction. Vol.15, No.7, pp.1552-1561, ISSN 02681161.

Eley, A., Hosseinzadeh, S.; Hakimi, H.; Geary, I. \& Pacey, A.A. (2005). Apoptosis of ejaculated human sperm is induced by co-incubation with Clamydia trachomatis lipopolysaccharide. Human Reproduction. Vol.20, No.9, pp.2601-2607, ISSN 02681161.

Erkkilä, K.; Hirvonen, V.; Wuokko, E.; Parvinen, M. \& Dunkel, L. (1998). N-acetyl-L-cysteine inhibits apoptosis in human male germ cells in vitro. The Journal of clinical endocrinology and metabolism. Vol.83, No.7, pp.2523-2531, ISSN 0021-972X.

Espino, J.; Bejarano, I.; Ortiz, A.; Lozano, G.M.; García, J.F.; Pariente, J.A. \& Rodríguez, A.B. (2010). Melatonin as a potential tool against oxidative damage and apoptosis in ejaculated human spermatozoa. Fertility and Sterility. Vol.94, No.9, pp.1915-1917, ISSN 0015-0282. 
Espino, J.; Ortiz, A.; Bejarano, I.; Lozano, G.M.; Monllor, F.; García, J.F.; Rodríguez, A.B. \& Pariente, J.A. (2011). Melatonin protects human spermatozoa from apoptosis via melatonin receptor- and extracelular-regulated kinase-mediated pathways. Fertility and Sterility. Vol.95, No.7, pp.2290-2296, ISSN 0015-0282.

Espinosa, F.; López-González, I.; Muñoz-Garay, C.; Felix, R.; De la Vega-Beltrán, J.L.; Kopf, G.S.; Visconti, P.E. \& Darszon, A. (2000). Dual regulation of the T-type $\mathrm{Ca}^{2+}$ current by serum albumin and betaestradiol in mammalian spermatogenic cells. FEBS Letter. Vol.475, No.3, pp.251-256, ISSN 0014-5793.

Espinoza, J.A.; Paasch, U. \& Villegas, J.V. (2009). Mitochondrial membrane potential disruption pattern in human sperm. Human reproduction. Vol.24, No.9, pp.20792085, ISSN 0268-1161.

Francavilla, S.; D'Abrizio, P.; Cordeschi, G.; Pelliccione, F.; Necozione, S.; Ulises, S.; Properzi, G. \& Francavilla, F. (2002). Fas expresión correlatos with human germ cell degeneration in meiotic and post-meiotic arrest of spermatogenesis. Molecular Human Reproduction. Vol.8, No.3, pp.213-220, ISSN 1360-9947.

Fujinoki, M. (2008). Melatonin-enhanced hyperactivation of hamster sperm. Reproduction. Vol.136, No.5, pp.533-541, ISSN 1470-1626.

Gallon, F.; Marchetti, C.; Jouy, N. \& Marchetti, P. (2006). The functionality of mitochondria differentiates human spermatozoa with high and low fertilizing capability. Fertility and sterility. Vol.86, No.5, pp.1526-1530, ISSN 0015-0282.

Green, D.R. \& Reed, J.C. (1998). Mitochondria and apoptosis. Science. Vol.281, No.5381, pp.1309-1312, ISSN 0036-8075.

Griveau, J.F.; Dumont, E.; Renard, P.; Callegari, J.P. \& Le Lannou, D. (1995). Reactive oxygen species, lipid peroxidation and enzymatic defence systems in human spermatozoa. Reproduction and Fertility. Vol.103, No.1, pp.17-26, ISSN 0022-4251.

Grunewald, S.; Baumann, T.; Paasch, U. \& Glander, H.J. (2006). Capacitation and acrosome reaction in nonapoptotic human spermatozoa. Annals of the New York Academy of Sciences. Vol.1090, pp.138-146, ISSN 0077-8923.

Grunewald, S.; Kriegel, C.; Baumann, T.; Glander, H.J. \& Paasch, U. (2009a). Interactions between apoptotic signal transduction and capacitation in human spermatozoa. Human reproduction. Vol.24, No.9, pp.2071-2078, ISSN 0268-1161.

Grunewald, S.; Paasch, U. \& Glander, H.J. (2001). Enrichment of non-apoptotic human spermatozoa after cryopreservation by immunomagnetic cell sorting. Cell and Tissue Banking. Vol.2, No. 3, pp.127-133, ISSN 1389-9333.

Grunewald, S.; Paasch, U.; Glander, H.J. \& Anderegg, U. (2005). Mature human spermatozoa do not transcribe novel RNA. Andrologia. Vol.37, No.2-3, pp.69-71, ISSN 0303-4569.

Grunewald, S.; Sharma, R.; Paasch, U.; Glander, H.J. \& Agarwal, A. (2009b). Impact of caspase activation in human spermatozoa. Microscopy Research and Technology. Vol.2, No.11, pp.878-888, ISSN 1059-910X.

Hajnoczky, G.; Davies, E. \& Madesh, M. (2003). Calcium signaling and apoptosis. Biochemical and biophysical research communications. Vol.304, No.3, pp.445-454, ISSN 0006291X. 
Hardeland, R.; Tan, D.X. \& Reiter, R.J. (2009). Kynuramines, metabolites of melatonin and other indoles: the resurrection of an almost forgotten class of biogenic amines. Journal of pineal research. Vol.47, No.2, pp.109-126, ISSN 0742-3098.

Ho, H.C. \& Suarez, S.S. (2001a). Hyperactivation of mammalian spermatozoa: function and regulation. Reproduction. Vol.122, No.4, pp.519-526, ISSN 1470-1626.

Ho, H.C. \& Suarez, S.S. (2001b). An inositol 1,4,5-trisphosphate receptor-gated intracellular $\mathrm{Ca} 2+$ store is involved in regulating sperm hyperactivated motility. Bilogy of Reproduction. Vol.65, No.5, pp.1606-1615, ISSN 0006-3363.

Hsueh, A.J.; Billing, H. \& Tsafriri, A. (1994). Ovarian follicle atresia: a hormonally controlled apoptotic process. Endocrine Reviews. Vol.15, No.6, pp.707-724, ISSN 0163769X.

Jagannathan, S.; Publicover, SJ.; Barratt, CL. (2000). Voltage-operated calcium channels in male germ cells. Reproduction. Vol.123, pp.203-215, ISSN1470-1626.

Jana, K.; Jana, N.; De, D.K. \& Guha, S.K. (2010). Ethanol induces mouse spermatogenic cell apoptosis in vivo through over-expression of Fas/Fas-L, p53, and caspase-3 along with cytochrome $\mathrm{c}$ translocation and glutathione depletion. Molecular Reproduction E Development. Vol.77, No.9, pp.820-833, ISSN 1040-452X.

Jia, X.D.; Zhou, D.X. \& Song, T.B. (2008). The reproductive system impairment of adult male rats induced by cocaine. Journal of forensic medicine. Vol.24, No.6, pp.411-413, ISSN 1004-5619.

Kerr, J.F.; Wyllie, A.H. \& Currie, A.R. (1972). Apoptosis: a basic biological phenomenon with wide-ranging implications in tissue kinetics. British Journal of Cancer. Vol.26, No.4, pp.239-257, ISSN 0007-0920.

Khorsandi, L.S.; Hashemitabar, M.; Orazizadeh, M. \& Albughobeish, N. (2008). Dexamethasone effects on fas ligand expression in mouse testicular germ cells. Pakistan Journal of Biological Science. Vol.15, No.11-18, pp.2231-2236, ISSN 10288880 .

Koji, T. (2001). Male germ cell death in mouse testes: possible involvement of Fas and Fas ligand. Medical electron microscopy : official journal of the Clinical Electron Microscopy Society of Japan. Vol.34, No.4, pp.213-22, ISSN 0918-4287.

Koji, T.; Hishikawa, Y.; Ando, H.; Nakanishi, Y. \& Kobayashi, N. (2001). Expression of Fas and Fas ligand in normal and ischemia-reperfusion testes: involvement of the Fas system in the induction of germ cell apoptosis in the damaged mouse testis. Biology of Reproduction. Vol.64, No.3, pp.946-954, ISSN 0006-3363.

Kothari, S.; Thompson, A.; Agarwal, A. \& Du Plessis, S.S. (2010). Free radicals: their beneficial and detrimental effects on sperm function. Indian Journal of Experimental Biology. Vol.48. No.5, pp.425-35, ISSN 0019-5189.

Kumar, R.; Jagan Mohanarao, G.; Arvind. \& Atreja, S.K. (2011). Freeze-thaw induced genotoxicity in buffalo (Bubalus bubalis) spermatozoa in relation to total antioxidant status. Molecular biology reports. Vol.38, No.3, pp.1499-1506, ISSN 03014851.

Kurosaka, K.; Takahashi, M.; Watanabe, N. \& Kobayashi, Y. (2003). Silent cleaup of very early apoptotic cells by macrophages. The Journal of Immunology. Vol.171, No.9, pp.4672-4679, ISSN 0022-1767. 
Leon, J.; Acuña-Castroviejo, D.; Sainz, R.M.; Mayo, J.C.; Tan, D.X. \& Reiter, R.J. (2004). Melatonin and mitochondrial function. Life sciences. Vol.75, No.7, pp.765-790, ISSN 0024-3205.

Li, H.; Zhu, H.; Xu, CJ. \& Yuan, J. (1998). Cleavage of BID by caspase 8 mediates the mitochondrial damage in the Fas pathway of apoptosis. Cell. Vol. 94, No.4, pp.491501, ISSN 0092-8674.

Li, P.; Nijhawan, D.; Budihardjo, I.; Srinivasula, S.M.; Ahmad, M.; Alnemri, E.S. \& Wang, X. (1997). Cytochrome $c$ and dATP-dependent formation of Apaf-1/caspase-9 complex initiates an apoptotic protease cascade. Cell. Vol.91, No, 4, pp.479-489, ISSN 0092-8674.

Li, Z.; Lin, Q.; Liu, R.; Xiao, W. \& Liu, W. (2010). Protective effects of ascorbate and catalase on human spermatozoa during cryopreservation. Journal of andrology. Vol.31, No.5, pp.437-444, ISSN 0196-3635.

Lin, W.W.; Lamb, D.J.; Wheeler, T.M.; Abrams, J.; Lipshultz, L.I. \& Kim, E.D. (1997). Apoptotic frequency is increased in spermatogenic maturation arrest and hypospermatogenic states. Journal of Urology. Vol.158, No.5, pp.1791-1793, ISSN 0022-5347.

Linsenmeyer, T.A. \& Perkash, I. (1991). Infertility in men with spinal cord injury. Archives of physical medicine and rehabilitation. Vol.72, No.10, pp.747-754, ISSN 0003-9993.

Lizama, C.; Alfaro, I.; Reyes, J.G. \& Moreno, R.D. (2007). Up-regulation of CD95 (Apo-1/Fas) is associated with spermatocute apoptosis during the first round spermatogenesis in the rat. Apoptosis . Vol.12, No.3, pp.499-512, ISSN 1360-8185.

Lozano, G.M.; Bejarano, I.; Espino, J.; Gonzalez, D.; Ortiz, A.; Garcia, J.F.; Rodríguez, A.B. \& Pariente, J.A. (2009). Relationship berween caspase activity and apoptotic markers in human sperm in response to hydrogen peroxide and progesterone. Journal of Reproduction and Development. Vol.55, No.6, pp.615-621, ISSN 0916-8818.

Makker, K.; Agarwal, A. \& Sharma, R. (2009). Oxidative stress \& male infertility. The Indian journal of medical research. Vol.129, No.4, pp.357-67, ISSN 0971-5916.

Marchetti, C.; Jouy, N.; Leroy-Martin, B.; Defossez, A.; Formstecher, P. \& Marchetti, P. (2004). Comparison of four fluorochromes for the detection of the inner mitochondrial membrane potential in human spermatozoa and their correlation with sperm motility. Human reproduction. Vol.19, No.10, pp.2267-2276, ISSN 02681161.

Martin, G.; Cagnon, N.; Sabido, O.; Sion, B.; Grizard, G.; Durand, P. \& Levy, R. (2007). Kinetics of occurrence of some features of apoptosis during the cryopreservation process of bovine spermatozoa. Human Reproduction. Vol.22, No.2, pp.380-388, ISSN 0268-1161.

Martin, G.; Sabido, O.; Durand, P. \& Levy, R. (2005). Phosphatidylserine externalization in human sperm induced by calcium ionophore A23187: relationship with apoptosis, membrane scrambling and the acrosome reaction. Human Reproduction. Vol.20, No.12, pp.3459-3468, ISSN 0268-1161.

Martínez, RR.; Luna, M. \& Chavarría, ME. (1987) Concentrations of calmodulin in sperm in relation to their motility in fertile euspermic and infertile asthenozoospermic men. International journal of andrology. Vol.10, No.3, pp.507-515, ISSN 0105-6263.

Meseguer, M.; Garrido, N.; Martínez-Conejero, JA.; Simón, C.; Pellicer, A. \& Remohí, J. (2004). Relationship between standard semen parameters, calcium, cholesterol 
contents and mitochondrial activity in ejaculated spermatozoa from fertile and infertile males. Journal of assisted reproduction and genetics. Vol.21, No.12, pp. 445451, ISSN 1058-0468.

Mishra, DP.; Pal, R. \& Shaha, C. (2006). Changes in Cytosolic Ca ${ }^{2+}$ Levels Regulate Bcl-xS and Bcl-xL Expression in Spermatogenic Cells during Apoptotic Death. The Journal of biological chemistry. Vol.281, No.4, pp.2133-2143, ISSN 0021-9258.

Morita, Y. \& Tilly, J.L. (1999). Oocyte apoptosis: like sand through an hourglass. Developmental biology. Vol.213, No.1, pp. 1-17, ISSN 0012-1606.

Mueller, T.; Voigt, W.; Simon, H.; Fruehauf, A.; Bulankin, A.; Grothey, A. \& Schmoll, H.J. (2003). Failure of activation of caspase-9 induces a higher threshold for apoptosis and cisplatin resistance in testicular cancer. American Association for Cancer Research. Vol.63, No.2, pp.513-521, ISSN 0008-5472.

Müller, M.; Wilder, S.; Bannasch, D.; Israeli, D.; Lehlbach, K.; Li-Weber, M.; Friedman, S.L.; Galle, P.R.; Stremmel, W.; Oren, M. \& Krammer, P.H. (1998). p53 activates the CD95 (APO-1/Fas) gene in response to DNA damage by anticancer drugs. The Journal of experimental medicine. Vol.188, No.11, pp.2033-2045, ISSN 00221007.

Murdoch, W.J. (2000). Proteolytic and cellular death mechanisms in ovulatory ovarian rupture. Biological signals and receptors. Vol.9, No.2, pp.102-114, ISSN 1422-4933.

Nicholson, D.W. (1999)Caspase structure, proteolytic substrates, and function during apoptotic cell death. Cell death and differentiation. Vol.6, No.11, pp.1028-1042, ISSN 1350-9047.

Oehninger, S.; Blackmore, P.; Mahony, M. \& Hodgen, G. (1995). Effects of hydrogen peroxide on human spermatozoa. Journal of assisted reproduction and genetics. Vol.12, No.1, pp.41-47, ISSN 1058-0468.

Oehninger, S.; Morshedi, M.; Weng. S.L.; Taylor, S.; Duran, H. \& Beebe, S. (2003). Presence and significance of somatic cell apoptosis markers in human ejaculated spermatozoa. Reproductive biomedicine online. Vol.7, No.4, pp.469-476, ISSN 14726483.

Oldereid, N.N.; Angelis, P.D.; Wiger, R. \& Clausen, O.P. (2001). Expression of Bcl-2 family proteins and spontaneous apoptosis in normal human testis. Molecular human reproduction. Vol.7, No.5, pp.403-408, ISSN 1360-9947.

Omezzine, A.; Chater, S.; Mauduit, C.; Florin, A.; Tabone, E.; Chuzel, F.; Bars, R. \& Benahmed, M. (2003) Long-term apoptotic cell death process with increased expression and activation of caspase- 3 and -6 in adult rat germ cells exposed in utero to flutamide. Endocrinology. Vol.144, No.2, pp.648-661, ISSN 0013-7227.

Ozaki, Y.; Blomgren, K., Ogasawara, M.S.; Aoki, K.; Furuno, T.; Nakanishi, M.; Sasaki, M. \& Suzumori, K. (2001). Role of calpain in human sperm activated by progesterone for fertilization. Biological chemistry. Vol.382, No.5, pp.831-838, ISSN 1431-6730.

Paasch, U.; Grunewald, S.; Dathe, S. \& Glander, H.J. (2004). Mitochondria of human spermatozoa are preferentially susceptible to apoptosis. Annals of the New York Academy of Sciences. Vol.1030, pp.403-409, ISSN 0077-8923.

Paasch, U.; Grunewald, S.; Fitzl, G. \& Glander, H.J. (2003). Deterioration of plasma membrane is associated with activation of caspases in human spermatozoa. Journal of andrology. Vol.24, No.2, pp.246-252, ISSN 0196-3635. 
Paudel, K.P.; Kumar, S.; Meur, S.K. \& Kumaresan, A. (2010). Ascorbic acid, catalase and chlorpromazine reduce cryopreservation-induced damages to crossbred bull spermatozoa. Reproduction in domestic animals. Vol.45, No.2, pp.256-262, ISSN 09366768.

Perticarari, S.; Ricci, G.; Boscolo, R.; De Santis, M.; Pagnini, G.; Martinelli, M. \& Presani, G. (2008). Fas receptor is not present on ejaculated human sperm. Human Reproduction. Vol.23, No.6, pp.1271-1279, ISSN 0268-1161.

Plante, M.; de Lamirande, E. \& Gagnon, C. (1994). Reactive oxygen species released by activated neutrophils, but not by deficient spermatozoa, are sufficient to affect normal sperm motility. Fertility and sterility. Vol.62, No.2, pp.387-393, ISSN 00150282.

Primakoff, P. \& Myles, D.G. (2002). Penetration, adhesion, and fusion in mammalian spermegg interaction. Science. Vol. 296, No.5576, pp.2183-2185, ISSN 0036-8075.

Purohit, S.B.; Laloraya, M. \& Kumar, G.P. (1999). Role of ions and ion channels in capacitation and acrosome reaction of spermatozoa. Asian journal of andrology. Vol.1, No.3, pp.95-107, ISSN 1008-682X.

Reed, J.C. (1997). Double identity for proteins of the Bcl-2 family. Nature. Vol.387, No.6635, pp.773-776, ISSN 0028-0836.

Reiter, R.J.; Tan, D.X.; Manchester, L.C.; Paredes, S.D; Mayo, J.C. \& Sainz, R.M. (2009). Melatonin and reproduction revisited. Biology of reproduction. Vol.81, No.3, pp.445456, ISSN 0006-3363.

Ren, D.; Navarro, B.; Pérez, G.; Jackson, A.C.; Hsu, S.; Shi, Q.; Tilly, J.L. \& Clapham, D.E. (2001). A sperm ion channel required for sperm motility and male fertility. Nature. Vol.413, No.6856, pp:603-609, ISSN 0028-0836.

Riccioli, A.; Dal Secco, V.; De Cesaris, P.; Starace, D.; Gandini, L.; Lenzi, A.; Dondero, F.; Padula, F.; Filippini, A. \& Ziparo, E. (2005). Presence of membrane and soluble forms of Fas ligand and of matrilysin (MMP-7) activity in normal and abnormal human semen. Human Reproduction. Vol.20, No.10, pp.2814-2820, ISSN 0268-1161.

Riccioli, A.; Salvati, L.; D'Alessio, A.; Starace, D.; Giampietri, C.; De Cesaris, P.; Filippini, A. \& Ziparo, E. (2003). The Fas system in the seminiferous epithelium and its possible extra-testicular role. Andrologia. Vol.35, No.1, pp.64-70, ISSN 0303-4569.

Richburg, J.H.; Nañez, A.; Williams, L.R.; Embree, M.E. \& Boekelheide, K. (2000). Sensitivity of testicular germ cells to toxicant-induced apoptosis in gld mice that express a nonfunctional form of Fas ligand. Endocrinology. Vol.141, No.2, pp.787-793; ISSN 0013-7227.

Rodeheffer, C. \& Shur, B.D. (2004b). Sperm from beta-1,4-galactosyltransferase I-null mice exhibit precocious capacitation. Development. Vol.131, No.3, pp.491-501, ISSN 09501991.

Rodriguez, C.; Mayo, J.C.; Sainz, R.M.; Antolín, I.; Herrera, F.; Martín, V. \& Reiter, R.J. (2004). Regulation of antioxidant enzymes: a significant role for melatonin. Journal of pineal research. Vol.36, No.1, pp.1-9, ISSN 0742-3098.

Rodriguez, I.; Ody, C.; Araki, K.; Garcia, I. \& Vassalli, P. (1997). An early and massive wave of germinal cell apoptosis is required for the development functional spermatogenesis. The EMBO journal. Vol.16, No.9, pp.2262-2270, ISSN 02614189. 
Rucker, E.B. 3 ${ }^{\text {rd }}$; Dierisseau, P.; Wagner, K.U.; Garrett, L.; Wynshaw-Boris, A.; Flaws, J.A. \& Hennighausen, L. (2000). Bcl-x and Bax regulate mouse primordial germ cell survival and apoptosis during embryogenesis. Molecular endocrinology. Vol.14, No.7, pp.1038-1052, ISSN 0888-8809.

Ruwanpura, S.M.; McLachlan, R.I. \& Meachem, S.J. (2010). Hormonal regulation of male germ cell development. The Journal of endocrinology. Vol.205, No.2, pp.117-131, ISSN 0022-0795.

Said, T.M.; Agarwal, A.; Grunewald, S.; Rasch, M.; Baumann, T.; Kriegel, C.; Li, L.; Glander, H.J.; Thomas, A.J. Jr. \& Paasch, U. (2005). Selection of non-apoptotic spermatozoa as a new tool for enhancing assisted reproduction outcomes: an in vivo model. Biology of reproduction. Vol.74, No.3, pp.530-537, ISSN 0006-3363.

Sailer, B:L.; Jost, L.K. \& Evenson, D.P. (1995). Mammalian sperm DNA susceptibility to in situ denaturation associated with the presence of DNA strand breaks as measured by the terminal deoxynucleotidyl transferase assay. Journal of andrology. Vol.16, No.1, pp.80-87, ISSN 0196-3635.

Sainz, R.M.; Mayo, J.C.; Rodriguez, C.; Tan, D.X.; Lopez-Burillo, S. \& Reiter, R.J. (2003). Melatonin and cell death: differential actions on apoptosis in normal and cancer cells. Cellular and molecular life sciences. Vol.60, No.7, pp.1407-1426, ISSN 1420$682 X$.

Sakkas, D.; Mariethoz, E. \& St John, J.C. (1999a). Abnormal sperm parameters in humans are indicative of an abortive apoptotic mechanism linked to the Fas-mediated pathway. Experimental cell research. Vol.251, No.2, pp.350-355, ISSN 0014-4827.

Sakkas, D.; Mariethoz, E.; Manicardi, G.; Bizzaro, D.; Bianchi, P:G. \& Bianchi, U. (1999b). Origin of DNA damage in ejaculated human spermatozoa. Reviews of reproduction. Vol.4, No.1, pp.31-37, ISSN 1359-6004.

Saleh, R.A.; Agarwal, A.; Sharma, R.K.; Nelson, D.R. \& Thomas, A.J. Jr. (2001). Effect of cigarette smoking on levels of seminal oxidative stress in infertile men: a prospective study. Fertility and Sterility. Vol.78, No.3, pp.491-499, ISSN 0015-0282.

Shaha, C. (2007). Modulators of spermatogenic cell survival. Society of Reproduction and Fertility supplement. Vol.63, pp.173-186.

Shekarriz, M.; Thomas, A.J. Jr. \& Agarwal, A. (1995). Incidence and level of seminal reactive oxygen species in normal men. Urology. Vol.45, No.1, pp.103-107, ISSN00904295.

Sikka, S.C.; Rajasekaran, M. \& Hellstrom, W.J. (1995). Role of oxidative stress and antioxidants in male infertility. Journal of andrology. Vol.16, No.6, pp.464-468, ISSN 0196-3635.

Sinha-Hikim, A.P. \& Swerdloff, R.S. (1999). Hormonal and genetic control of germ cell apoptosis in the testis. Reviews of reproduction. Vol.4, No.1, pp.38-47, ISSN 13596004.

Sinha-Hikim, A.P.; Lue, Y.; Diaz-Romero, M.; Yen, P.H.; Wang, C. \& Swerdloff, R.S. (2003). Deciphering the pathways of germ cell apoptosis in the testis. The Journal of steroid biochemistry and molecular biology. Vol.85, No.2-5, pp.175-182, ISSN 09600760 .

Soleimani, M.; Tavalaee, M.; Aboutorabi, R.; Adib, M.; Bahramian, H.; Janzamin, E.; Kiani, A. \& Nasr-Esfahani, M.H. (2010) Evaluation of Fas positive sperm and complement 
mediated lysis in subfertile individuals. Journal of assisted reproduction and genetics. Vol.27, No.8, pp.477-482, ISSN 1058-0468.

Stennicke, H.T. \& Salvesen, G.S. (1997). Biochemical characteristics of capase-3, -6, -7, and -8. The Journal of biological chemistry. Vol.272, No.41, pp.25719-25723, ISSN 0021-9258.

Suda, T.; Takahashi, T.; Golstein, P. \& Nagata, S. (1993). Molecular cloning and expression of the Fas ligand, a novel member of the tumor necrosis factor family. Cell. Vol.75, No.6, pp.1169-1178, ISSN 0092-8674.

Taylor, S.L.; Weng, S.L.; Fox, P.; Duran, E.H.; Morshedi, M.S.; Oehninger, S. \& Beebe, S.J. (2004). Somatic cell apoptosis markers and pathways in human ejaculated sperm: potential utility as indicators of sperm quality. Molecular human reproduction. Vol.10, No.11, pp.825-834, ISSN 1360-9947.

Thuwanut, P.; Chatdarong, K.; Johannisson, A.; Bergqvist, A.S.; Söderquist, L. \& Axnér, E. (2010). Cryopreservation of epididymal cat spermatozoa: effects of in vitro antioxidative enzymes supplementation and lipid peroxidation induction. Theriogenology. Vol.73, No.8, pp.1076-1087, ISSN 0093-691X.

Tremellen, K. (2008). Oxidative stress and male infertility - a clinical perspective. Human reproduction update. Vol.14, No.3, pp.243-258, ISSN 1355-4786.

Trevino, C.L.; Félix, R.; Castellano, L.E.; Gutiérrez, C.; Rodriguez, D.; Pacheco, J.; LópezGonzález, I.; Gomora, J.C.; Tsutsumi, V.; Hernández-Cruz, A.; Fiordelisio, T.; Scaling, A.L. \& Darszon, A. (2004). Expression and differential cell distribution of low-threshold $\mathrm{Ca}^{2+}$ channels in mammalian male germ cells and sperm. FEBS letters. Vol.563, No.1-3, pp.87-92, ISSN 0014-5793.

Tripathi, D.N. \& Jena, G.B. (2008). Astaxanthin inhibits cytotoxic and genotoxic effects of cyclophosphamide in mice germ cells. Toxicology. Vol.248, No.2-3, pp.96-103, ISSN 0300-483X.

Troiano, L.; Granata, A.R.; Cossarizza, A.; Kalashnikova, G.; Bianchi, R.; Pini, G.; Tropea, F.; Carani, C. \& Franceschi, C. (1998). Mitochondrial membrane potential and DNA stainability in human sperm cells: a flow cytometry analysis with implications for male infertility. Experimental cell research. Vol.241, No.2, pp.384-393, ISSN 0014-4827.

Tunc, O.; Thompson, J. \& Tremellen, K. Improvement in sperm DNA quality using an oral antioxidant therapy. (2009). Reproductive biomedicine online. Vol.18, No.6, pp.761768, ISSN 1472-6483.

Vasudevan, S.R.; Lewis, A.M.; Chan, J.W.; Machin, C.L.; Sinha, D.; Galione, A. \& Churchill, G.C. (2010). The calcium-mobilizing messenger nicotinic acid adenine dinucleotide phosphate participates in sperm activation by mediating the acrosome reaction. J The Journal of biological chemistry. Vol.285, No.24, pp.18262-18269. ISSN 00219258.

Vine, M.F. (1996). Smoking and male reproduction: a review. International journal of andrology. Vol.19, No.6, pp.323-337, ISSN 0105-6263.

Wang, K.K.; Posmantur, R.; Nadimpalli, R.; Nath, R.; Mohan, P.; Nixon, R.A.; Talanian, R.V.; Keegan, M.; Herzog, L. \& Allen, H. (1998). Caspase-mediated fragmentation of calpain inhibitor protein calpastatin during apoptosis. Archives of biochemistry and biophysics. Vol.356, No.2, pp.187-196, ISSN 0003-9861.

Wang, Q.; Zhao, X.F.; Ji, Y.L.; Wang, H.; Liu, P.; Zhang, C.; Zhang, Y. \& Xu, D.X. (2010). Mitochondrial signaling pathway is also involved in bisphenol A induced 
germ cell apoptosis in testes. Toxicology letters. Vol.199, No.2, pp.129-135, ISSN $0378-4274$.

Wang, X. (2001). The expanding role of mitochondria in apoptosis. Genes $\mathcal{E}$ development. Vol.15, No.22, pp.2922-2933, ISSN 0890-9369.

Weil, M.; Jacobson, M.D. \& Raff, M.C. (1998). Are caspases involved in the death of cells with a transcriptionally inactive nucleus? Sperm and chicken erythrocytes. Journal of cell science. Vol.111, No.Pt18, pp. 2707-2715, ISSN 0021-9533.

Yan, W.; Suominen, J.; Samson, M.; Jegou, B. \& Toppari, J. (2000). Involvement of Bcl-2 family proteins in germ cell apoptosis during testicular development in the rat and pro-survival effect of stem cell factor on germ cells in vitro. Molecular and cellular endocrinology. Vol.165, No.1-2, pp.115-129, ISSN 0303-7207.

Yazawa, T.; Fujimoto, K.; Yamamoto, T. \& Abé, S.I. (2001). Caspase activity in newt spermatogonial apoptosis induced by prolactin and cycloheximide. Molecular reproduction and development. Vol.59, No.2, pp.209-214, ISSN 1040-452X.

Yazawa, T.; Yamamoto, T. \& Abé, S. (2000). Prolactin induces apoptosis in the penultimate spermatogonial stage of the testes in Japanese red-bellied newt (Cynops pyrrhogaster). Endocrinology. Vol.141, No.6, pp.2027-2032, ISSN 0013-7227.

Yudin, A.I.; Goldberg, E.; Robertson, K.R. \& Overstreet, J.W. (2000). Calpain and calpastatin are located berween the plasma membrane and outer acrosomal membrane of cynomolgus macaque spermatozoa. Journal of andrology. Vol.21, No.5, pp.721-729, ISSN 0196-3635. 


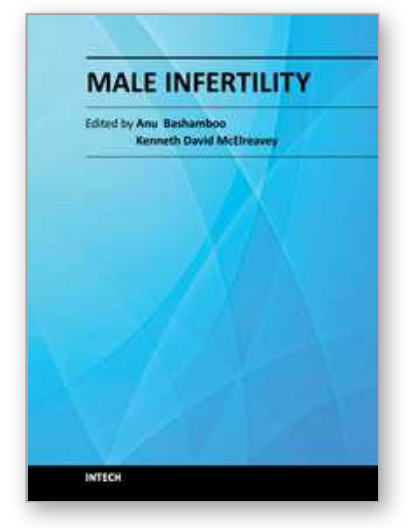

\author{
Male Infertility \\ Edited by Dr. Anu Bashamboo
}

ISBN 978-953-51-0562-6

Hard cover, 194 pages

Publisher InTech

Published online 20, April, 2012

Published in print edition April, 2012

Male infertility is a multifaceted disease where genetic, epigenetic and environmental factors all contribute to the development of the phenotype. In recent years, there has been an increasing concern about a decline in reproductive health, paralleled by an increase in demand for infertility treatments. This calls for a detailed and thorough understanding of normal and aberrant testicular function and the environmental influences on the establishment and integrity of the male germ cell. This is crucial for understanding the complex pathophysiology of male infertility and eventual success of Assisted Reproductive Technologies.

\title{
How to reference
}

In order to correctly reference this scholarly work, feel free to copy and paste the following:

Ignacio Bejarano, Javier Espino, Sergio D. Paredes, Águeda Ortiz, Graciela Lozano, José Antonio Pariente, Ana B. Rodríguez (2012). Apoptosis, ROS and Calcium Signaling in Human Spermatozoa: Relationship to Infertility, Male Infertility, Dr. Anu Bashamboo (Ed.), ISBN: 978-953-51-0562-6, InTech, Available from: http://www.intechopen.com/books/male-infertility/apoptosis-ros-and-calcium-signaling-in-human-spermatozoarelationship-to-infertility

\section{INTECH}

open science | open minds

\section{InTech Europe}

University Campus STeP Ri

Slavka Krautzeka 83/A

51000 Rijeka, Croatia

Phone: +385 (51) 770447

Fax: +385 (51) 686166

www.intechopen.com

\section{InTech China}

Unit 405, Office Block, Hotel Equatorial Shanghai

No.65, Yan An Road (West), Shanghai, 200040, China

中国上海市延安西路65号上海国际贵都大饭店办公楼 405 单元

Phone: +86-21-62489820

Fax: $+86-21-62489821$ 
(C) 2012 The Author(s). Licensee IntechOpen. This is an open access article distributed under the terms of the Creative Commons Attribution 3.0 License, which permits unrestricted use, distribution, and reproduction in any medium, provided the original work is properly cited. 